\title{
Studies on nutrient export and extent of nutrient recycling in coconut based high density multispecies cropping system
}

\author{
P. Subramanian ${ }^{1}$, D.V. Srinivasa Reddy ${ }^{1}$, C. Palaniswami ${ }^{1}$, P. Gopalasundaram ${ }^{2}$ and \\ A.K. Upadhyay ${ }^{3}$
}

\begin{abstract}
Investigations were carried out to assess the biomass available for recycling from coconut based high density multispecies cropping system (coconut, clove, banana and pineapple) under graded levels of fertilizers (full, two-third, one-third, one-fourth and one-fifth of the recommended level of fertilizer for each of the component crops and control). The total biomass removed from the system ranged from 19.1 to $27.6 \mathrm{t} \mathrm{ha}^{-1}$ year $^{-1}$. The highest biomass production was recorded from two-third level of fertilizer dose $\left(27.6 \mathrm{t} \mathrm{ha}^{-1} \mathrm{year}^{-1}\right)$. Out of the total biomass obtained, the quantity available for recycling ranged from 12.7 to $18.5 \mathrm{t} \mathrm{ha}^{-1}$ year $^{-1}$, which can contribute 56 to $110 \mathrm{~kg} \mathrm{~N}, 6.7$ to $13.5 \mathrm{~kg} \mathrm{P}$ and 108 to $225 \mathrm{~kg} \mathrm{~K}$ per hectare.
\end{abstract}

Key words: Nutrient recycling, high density multispecies, graded levels of fertilizers cropping system, coconut, clove, banana, pineapple.

\footnotetext{
${ }^{1}$ Division of Crop Production, Central Plantation Crops Research Institute, Kasaragod-671124, Kerala, India.

${ }^{2}$ Principal Scientist, Sugarcane Breeding Institute, Coimbatore. 641003, India.

3 Senior Scientist, National Research Center on Grapes, Pune. 412307, India.
} 


\section{Introduction}

High density multispecies cropping systems (HDMSCS) involve growing of a large number of crops per unit area to meet the diverse needs of the farmer such as food, fuel, timber, fodder and cash. They are ideally suited for small land holdings and aim at maximum utilization of natural resources in unit time without degrading the quality of environment. But, with many component crops, the chemical input load in the form of fertilizers on the soil to meet the crop needs is high. Fertilizers are becoming prohibitively costly because of the increase in the cost of raw materials and power used in the manufacturing process. In addition, the raw materials needed for their manufacture are either fossil fuels or mineral ores, which are getting depleted at a faster rate. Now a days there is greater awareness regarding soil health and organic farming. Under these situations sustaining the productivity to meet the evergrowing demand of the population while, protecting the quality of environment is the need of the hour. This can be achieved through judicious utilization of chemical fertilizers and organic manures. However, availability and cost of organic manure is the main constraint. Hence there is an urgent need to recycle the organic residues generated in high intensity cropping systems in an effective manner. The importance of intensive cropping lies in the nutrient economy, as the extensive cover in the plantation floor increases the plant cycling fraction of nutrients (Khanan and Nair, 1977). Coconut is being grown as a monocrop or in homestead gardens or in high density multispecies cropping systems. Coconut based homestead farming is capable of maintaining soil health and ensuring environmental safety and it is economically efficient, ecologically sound and biologically sustainable (Salam et al., 1991). Biomass productivity of coconut pineapple - intercropping system was 4.3 times that of pure coconut stands and this combination is considered to be one of the optimum cultivation patterns in tropical areas (Peng-FangRen et al., 1996).
Cocoa, as a component of multiple cropping system adds substantial quantity of organic matter to the soil, thus leading to internal recycling of nutrients in the system. It has been observed that 8.2 and $19.8 \mathrm{t} / \mathrm{ha} / \mathrm{year}$ (oven dry basis) of cocoa litter fall were obtained from single and double hedge systems of planting, respectively (Varghese et al., 1978). Taking nutrient concentration of cocoa leaves to be $2.84 \% \mathrm{~N}, 0.26 \% \mathrm{P}$ and $1.73 \% \mathrm{~K}$ on dry weight basis, it could be assumed that about $50 \mathrm{~kg} \mathrm{~N}, 11$ $\mathrm{kg} \mathrm{P}_{2} \mathrm{O}_{5}$ and $35 \mathrm{~kg} \mathrm{~K}_{2} \mathrm{O}$ could be returned to the soil every year through leaf fall of cocoa under double hedge system of mixed cropping.

The practice of growing large number of crops in the interspaces of coconut would add lot of biomass to the soil and indirect addition of nutrients. This makes it necessary to rationalise the fertilizers to the crops in the system. The results of HDMSCS model studied under different levels of recommended fertilizers for ten years at Kasaragod indicated that there was no marked yield difference of crops in the full and two-third levels of fertilizers. This indicates the scope for scaling down of the recommended fertilizer dose of different crops in the system (Anonymous, 1995). Coconut based highdensity multispecies cropping system generates large amount of biomass which if effectively recycled can meet major nutrient needs of the crop. The present investigation was therefore undertaken to study the annual biomass production of coconut and component crops and biomass available for recycling under various fertilizer levels in a coconut based high density multispecies cropping system.

\section{Materials and methods}

The present study was conducted over a period of two consecutive years (1998 and 1999) in an existing coconut based high density multispecies cropping system which was started in the year 1983 in the research farm of Central Plantation Crops Research Institute, Kasaragod, in an 18 years old WCT coconut garden. The coconut palms were spaced $8 \mathrm{~m}$ apart and arranged in square system of planting. Clove (132 
nos.), banana (343 nos.) and pineapple (3456 nos.) were grown as intercrops. The experiment was laid out in 1.2 ha area. Initially, the experimental plot had three treatments i.e. full, two-third and one-third of the recommended fertilizer dose for each component crop. Later, based on the results of ten years, the experiment was modified in 1994 with three more additional treatments. The treatment details are given in Table 1. Fertilizers were applied in two splits i.e., one-third immediately after the onset of southwest monsoon (May-June) and remaining two-third dose at the post-monsoon period (September-October). Perfo irrigation was provided at Irrigation Water/Cumulative Pan Evaporation ratio - 0.75 (irrigation water 20mm) from December-May.

Table 1: Treatment details

\begin{tabular}{|c|l|c|}
\hline Plot & \multicolumn{1}{|c|}{ Treatment } & $\begin{array}{c}\text { Plot size } \\
\text { (ha) }\end{array}$ \\
\hline I & Full level of recommended dose & 0.2 \\
\hline II & $2 / 3^{\text {rd }}$ level of recommended dose & 0.2 \\
\hline III & $1 / 3^{\text {rd }}$ level of recommended dose & 0.2 \\
\hline IV & $1 / 4^{\text {th }}$ level of recommended dose & 0.2 \\
\hline V & $1 / 5^{\text {th }}$ level of recommended dose & 0.2 \\
\hline VI & No fertilizer & 0.2 \\
\hline
\end{tabular}

Note: The recommended dose of coconut, clove, banana and pineapple is 500: 320: 1200, 300: 250: 750, 200:200:400 and 8: 4: $8 \mathrm{~g} \mathrm{~N}, \mathrm{P}_{2} \mathrm{O}_{5}$, $\mathrm{K}_{2} \mathrm{O} /$ plant/year, respectively.

\section{Method of sampling}

\section{a) Coconut}

Dry leaves: Total leaves in the crown were counted and the first fully opened leaf was marked in six palms/treatment (totally thirty six palms). Each year, the number of dried leaves fallen on the ground were counted from January to December. The samples were collected every quarter (February, May, August and November). The fallen leaves were separated in to petiole and leaflets and were weighed. Sub samples of each of these were oven dried and dry weight was estimated. The nutrient content of powdered dry samples was determined.

Inflorescence: Dry weight of spathe and bunch waste was estimated in a similar manner as mentioned above.

Nut components: Twelve nuts/tree were collected for nut component analysis during different periods starting from January to December. Nuts were stored under shade for one month and the weight of husk, copra and shell recorded. Sub samples were taken and oven dried for dry matter estimation and nutrient analysis.

\section{b) Banana}

Samples were collected at the time of harvest. Six plants per treatment (totally thirty six plants) were removed at the ground level at the time of harvest and aboveground biomass was estimated. The plants were dissected into leaves, pseudostem, peduncle and fruits. Each part was weighed separately and sub samples were taken. The various sub samples were oven dried and the percentage of oven dry matter and total dry weight of the whole plant was estimated. After milling, the samples were analysed separately for $\mathrm{N}, \mathrm{P}$ and $\mathrm{K}$ as per the standard procedures.

\section{c) Clove}

Totally thirty-six plants (six trees/treatment) were marked for biomass estimation. The fallen leaves and flower buds were accounted for the study. The fallen leaves were collected at fortnightly interval and flower buds once in a year for dry matter estimation and nutrient analysis.

\section{d) Pineapple}

One hundred and forty four plants at the rate of twenty four plants/treatment were collected at the time of harvest. Each plant was divided into root, stem, leaves, fruit and crown and weighed. From this, sub samples were taken. The various sub samples were weighed and dried in the oven at $70^{\circ} \mathrm{C}$, reweighed and the percentage of oven dry matter and total dry weight of the whole plant calculated. After powdering, they were analysed 
separately for $\mathrm{N}, \mathrm{P}$ and $\mathrm{K}$ as per the standard procedures.

\section{Results and discussion}

\section{Annual biomass removed from the system and amount available for recycling}

The data clearly revealed that the two- third and full dose of recommended level of fertilizer recorded higher amount of biomass and the lowest biomass was recorded in the unfertilized plots (Fig.1). The biomass produced in the system from main and different component crops was in the order of coconut, banana, clove and pineapple. Each crop is discussed below.

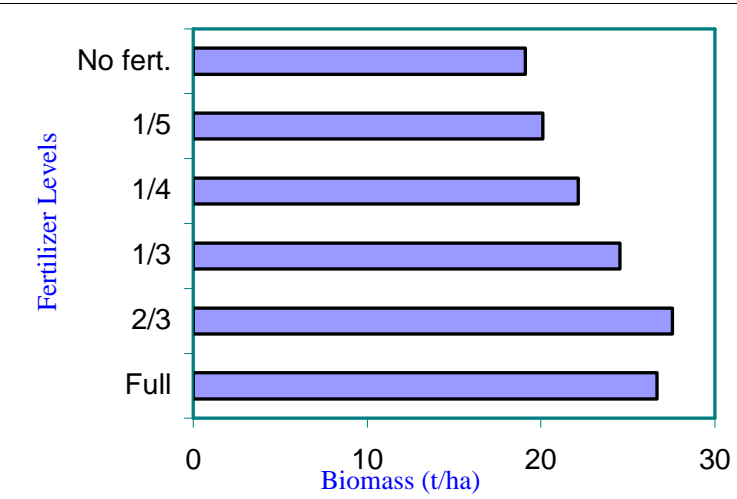

Fig. 1. Total removable biomass from the system

\section{Coconut}

The biomass removed from coconut was in the form of leaves, inflorescence waste and nuts. The annual biomass removed from the system ranged from 17.7 to $24.8 \mathrm{t} / \mathrm{ha} /$ year. The treatment two-third level recorded the highest biomass of $24.8 \mathrm{t} / \mathrm{ha} /$ year, which was comparable to full dose of fertilizer (23.6 t/ha/year). The lowest biomass was recorded in the control plot $(17.7 \mathrm{t} / \mathrm{ha} / \mathrm{yr})$. Ouvrier and Ochs (1980) estimated that dry matter production of Dwarf $\mathrm{x}$ West African Tall in the Ivory Coast was just over $30 \mathrm{t} / \mathrm{ha} /$ year with the copra yield of $6,700 \mathrm{~kg} / \mathrm{ha}$. The results clearly illustrate that when the fertilizer dose was reduced to two-third of the recommended level, the biomass production and yield of coconut palms could be sustained at very high levels, probably as a result of compensation from biomass recycling. The biomass available for recycling is presented in the Table 3. Leaves, inflorescence waste and husks were available for recycling. Like biomass production, more biomass available for recycling was recorded under two- third and full dose of fertilizer levels.

\section{Clove}

Total biomass removed from the system is presented in the Table 2. The biomass was removed in the form of leaves and flower buds. The highest biomass was produced when twothird dose of fertilizer was applied to the clove trees and the same declined gradually with the reduction in fertilizer level. The same trend was observed in the economic product also i.e. flower buds. This clearly indicated that when clove was grown as a component crop in the coconut based cropping system, two-third of the recommended level of fertilizer was required to realize higher biomass production. Out of total biomass removed from the system, only fallen leaves of clove will be available for recycling and total weight of fallen leaves per year is calculated and presented in Table 3. The highest amount of biomass available for recycling was recorded under two-third level of recommended dose of fertilizer $(800 \mathrm{~kg})$ and it gradually declined with the lowering of fertilzer dose. Nazeem et al. (1996) found that $3.8 \mathrm{~kg}$ of dry matter/tree was produced when clove was grown as monocrop under full fertilizer level.

\section{Banana}

The annual biomass removed from the banana in HDMSCS model including economic part ranged from 716 to $1767 \mathrm{~kg} / \mathrm{ha}$ (Table 2). The highest biomass production was from full dose of fertilizer and gradually decreased with reduction in the level of fertilizer application. Banana is a heavy feeder and the required fertilizer is supplied with in a shorter period of six to eight months. Therefore, the biomass 
recycling and the nutrient supply would not be affected to the same extent as that of perennial crops like coconut and clove. The part of banana available for recycling is pseudo stem and leaves. The highest level of recyclable biomass was recorded under full dose of the recommended level of fertilizer and followed the same trend as that of total biomass production under different fertilizer levels. The amount of biomass available for recycling ranged from 503 to $1295 \mathrm{~kg}$ /ha (Table 3).

\section{Pineapple}

Like banana, more amount of biomass was produced in the full dose of fertilizer and it gradually declined with the reduction in fertilizer dose. It clearly revealed that for higher biomass production, full dose of fertilizer is necessary when pineapple is grown as component crop (Table 2). The same trend was observed in biomass available for recycling also and it ranged from 263 to $435 \mathrm{~kg} / \mathrm{ha}$. Roots, peduncle, leaves and crown of pineapple were available for recycling (Table 3 ).

\section{Annual nutrient export and extent of nutrient recycling in the coconut system}

Irrespective of the level of fertilizer applied, potassium dominates in nutrient export, and ranged from 119.1 to $183.6 \mathrm{~kg} / \mathrm{ha}$ followed by nitrogen (92.4 to $149.3 \mathrm{~kg} / \mathrm{ha}$ ) and phosphorous (12.9 to $20.8 \mathrm{~kg} / \mathrm{ha}$ ) (Table 4). This clearly indicated that potassium and nitrogen are required in higher quantities for the mineral nutrition of coconut. Ochs and Ollaagnier (1977) concurred that potassium is the dominant element in fertilizer requirement of coconut. Manciot et al. (1979) estimated the annual total nutrient uptake for the whole palm (hybrids yielding $6.7 \mathrm{t}$ of copra/ha) as 174, 20 and $245 \mathrm{~kg}$ of N,P and K per ha, respectively. The extent of nutrient recycling through the biomass available is presented in the Table 5. It clearly reveals that there is a possibility of recycling nitrogen to the tune of 46.0 to $81.9 \mathrm{~kg} / \mathrm{ha}$ and phosphorous to the tune of 5.4 to $10.6 \mathrm{~kg} / \mathrm{ha}$ and potassium to the tune of 79.4 to $127.3 \mathrm{~kg} / \mathrm{ha}$. This also clearly indicates the vast scope for considerable reduction in fertilizer requirement, which can be achieved by effectively recycling the biomass available in the coconut garden. Ouvrier and de Taffin (1985) observed that leaving the husk in the field, where it was quickly broken down, released the locked up nutrients thereby reducing the inorganic fertilizer requirement of coconut.

\section{Clove}

The annul export of nutrients through leaf and flower buds ranged from 5.9 to $11.9,0.31$ to 0.58 and 7.6 to $15.7 \mathrm{~kg} / \mathrm{ha}$ for nitrogen, phosphorous and potassium respectively, under different levels of fertilizers (Table 4). The contribution from leaves could be recycled in the system was 5.5 to $10.8,0.28$ to 0.47 and 6.6 to $12.2 \mathrm{~kg} / \mathrm{ha}$ of N,P and K, respectively (Table 5).

\section{Banana}

Nutrient export from banana ranged from 3.6 to $16.1,0.6$ to 1.9 and 19.0 to $85.7 \mathrm{~kg} / \mathrm{ha}$ of $\mathrm{N}, \mathrm{P}$ and $\mathrm{K}$, respectively (Table 4). Out of this, the parts like pseudostem and leaves could be recycled. From this 2.9 to $13.2 \mathrm{~kg} \mathrm{~N}, 0.4$ to 1.5 $\mathrm{kg} \mathrm{P}$ and 14.9 to $73.7 \mathrm{~kg} \mathrm{~K}$ per hectare could possibly be ploughed back in to the system. (Table 5)

\section{Pineapple}

Nutrient export from root, peduncle, leaves, fruit and crown were calculated and it ranged from 2.6 to $5.5,0.7$ to 1.1 and 9.7 to $19.7 \mathrm{~kg} / \mathrm{ha}$ of N, P and K, respectively (Table 4). Except the fruit portion, all other parts could be recycled in to the system through which 1.9 to $4.4,0.6$ to 0.9 and 7.2 to $15.3 \mathrm{~kg}$ /ha of $\mathrm{N}, \mathrm{P}$ and $\mathrm{K}$ could be returned back to the soil (Table 5). observed in the no fertilizer treatment (Table 6). Among the nutrients exported by the crops, potassium export was the highest as potassium requirement for all the crops were very high. However, all the quantity of nutrients exported cannot be recycled back to the system as 
Table 2. Total annual biomass removal of coconut and component crops in the coconut based high-density multispecies cropping system under different fertilizer levels (t/ha)

\begin{tabular}{|l|c|c|c|c|c|}
\hline $\begin{array}{c}\text { Amount of Biomass } \\
\text { removal/crops }\end{array}$ & Coconut & Clove & Banana & Pineapple & Total \\
\hline Full & 23.55 & 0.762 & 1.767 & 0.585 & 26.664 \\
Two-third & 24.80 & 0.800 & 1.407 & 0.541 & 27.548 \\
One-third & 21.98 & 0.710 & 1.329 & 0.524 & 24.543 \\
One-fourth & 19.94 & 0.581 & 1.124 & 0.485 & 22.130 \\
One-fifth & 18.49 & 0.445 & 0.851 & 0.321 & 20.107 \\
Control & 17.72 & 0.349 & 0.716 & 0.315 & 19.100 \\
\hline
\end{tabular}

Table 3. Total annual biomass available for recycling from 1 ha of coconut based multispecies cropping system under different fertilizer levels(t/ha)

\begin{tabular}{|l|c|c|c|c|c|}
\hline $\begin{array}{c}\text { Amount of biomass } \\
\text { removal/crops }\end{array}$ & Coconut & Clove & Banana & Pineapple & Total \\
\hline Full & 15.80 & 0.666 & 1.295 & 0.435 & 18.196 \\
Two-third & 16.46 & 0.676 & 0.962 & 0.399 & 18.497 \\
One-third & 14.11 & 0.619 & 0.927 & 0.387 & 16.043 \\
One-fourth & 12.50 & 0.524 & 0.738 & 0.351 & 14.133 \\
One-fifth & 11.65 & 0.392 & 0.575 & 0.263 & 12.832 \\
Control & 11.60 & .349 & 0.503 & 0.215 & 12.667 \\
\hline
\end{tabular}

Table 4. Annual nutrient export of coconut and component crops from 1 ha of coconut based multispecies cropping system under different fertilizer levels $(\mathrm{kg} / \mathrm{ha})$

\begin{tabular}{|c|c|c|c|c|c|c|c|c|c|c|c|c|}
\hline \multirow{2}{*}{$\begin{array}{c}\text { Amount of } \\
\text { biomass } \\
\text { removal/crops }\end{array}$} & \multicolumn{3}{|c|}{ Coconut } & \multicolumn{3}{|c|}{ Clove } & \multicolumn{3}{|c|}{ Banana } & \multicolumn{3}{|c|}{ Pineapple } \\
\hline & $\mathrm{N}$ & $P$ & K & $\mathrm{N}$ & $P$ & K & $\mathrm{N}$ & $\mathrm{P}$ & K & $\mathrm{N}$ & $P$ & K \\
\hline Full & 149.3 & 20.8 & 179.3 & 11.9 & 0.58 & 13.0 & 16.1 & 1.9 & 85.7 & 5.5 & 1.1 & 19.7 \\
\hline Two-third & 139.4 & 18.4 & 183.6 & 11.9 & 0.59 & 15.7 & 10.6 & 1.7 & 69.0 & 5.2 & 1.0 & 19.3 \\
\hline One-third & 125.2 & 16.5 & 164.2 & 10.8 & 0.52 & 12.8 & 8.3 & 1.4 & 63.8 & 4.5 & 1.1 & 15.5 \\
\hline One-fourth & 106.3 & 16.8 & 135.1 & 7.4 & 0.47 & 10.6 & 6.7 & 1.2 & 37.1 & 4.2 & 1.0 & 13.9 \\
\hline One-fifth & 92.6 & 13.2 & 127.3 & 6.0 & 0.40 & 9.3 & 4.3 & 0.6 & 24.9 & 2.8 & 0.7 & 10.0 \\
\hline Control & 92.4 & 12.9 & 119.1 & 5.9 & 0.31 & 7.6 & 3.6 & 0.6 & 19.0 & 2.6 & 0.7 & 9.7 \\
\hline
\end{tabular}


Table 5. Annual possible nutrient recycling from 1 ha of coconut based multispecies cropping system under different fertilizer levels (kg/ha)

\begin{tabular}{|c|c|c|c|c|c|c|c|c|c|c|c|c|}
\hline \multirow{2}{*}{$\begin{array}{l}\text { Crops/ } \\
\text { nutrients }\end{array}$} & \multicolumn{3}{|c|}{ Coconut } & \multicolumn{3}{|c|}{ Clove } & \multicolumn{3}{|c|}{ Banana } & \multicolumn{3}{|c|}{ Pineapple } \\
\hline & $\mathrm{N}$ & $\mathrm{P}$ & $\mathrm{K}$ & $\mathrm{N}$ & $\mathrm{P}$ & $\mathrm{K}$ & $\mathrm{N}$ & $\mathrm{P}$ & K & $\mathrm{N}$ & $\mathrm{P}$ & $\mathrm{K}$ \\
\hline Full & 81.9 & 10.6 & 125.4 & 10.8 & 0.47 & 10.7 & 13.2 & 1.5 & 73.7 & 4.4 & 0.89 & 15.3 \\
\hline Two-third & 81.0 & 8.3 & 127.3 & 10.5 & 0.44 & 12.2 & 8.6 & 1.3 & 59.0 & 4.0 & 0.79 & 15.0 \\
\hline One-third & 67.0 & 7.2 & 110.4 & 9.8 & 0.42 & 10.5 & 6.6 & 0.9 & 54.3 & 3.7 & 0.92 & 12.3 \\
\hline One-fourth & 52.7 & 8.1 & 85.3 & 6.8 & 0.41 & 9.0 & 5.2 & 0.8 & 29.0 & 3.4 & 0.90 & 10.9 \\
\hline One-fifth & 47.6 & 5.7 & 83.9 & 5.5 & 0.34 & 7.9 & 3.4 & 0.4 & 19.6 & 2.0 & 0.60 & 8.5 \\
\hline Control & 46.0 & 5.4 & 79.4 & 5.6 & 0.28 & 6.6 & 2.9 & 0.4 & 14.9 & 1.9 & 0.64 & 7.2 \\
\hline
\end{tabular}

Table 6. Total nutrient export and recycling in the system $(\mathrm{kg} / \mathrm{ha})$

\begin{tabular}{|l|c|c|c|c|r|r|r|r|r|}
\hline \multirow{2}{*}{$\begin{array}{c}\text { Crops/ } \\
\text { nutrients }\end{array}$} & \multicolumn{3}{|c|}{ Total nutrient export } & \multicolumn{3}{c|}{ Total nutrient recycling } & \multicolumn{3}{c|}{$\begin{array}{c}\text { Total amount of } \\
\text { fertilizer applied }\end{array}$} \\
\cline { 2 - 11 } & $\mathrm{N}$ & \multicolumn{1}{c|}{$\mathrm{P}$} & \multicolumn{1}{c|}{$\mathrm{K}$} & \multicolumn{1}{c|}{$\mathrm{N}$} & \multicolumn{1}{c|}{$\mathrm{P}$} & \multicolumn{1}{c|}{$\mathrm{K}$} & $\mathrm{N}$ & $\mathrm{P}_{2} \mathrm{O}_{5}$ & \multicolumn{1}{c|}{$\mathrm{K}_{2} \mathrm{O}$} \\
\hline Full & 182.9 & 24.4 & 297.7 & 110.3 & 13.5 & 225.1 & 48 & 8 & 50 \\
\hline Two-third & 167.1 & 21.6 & 287.7 & 104.1 & 10.7 & 213.5 & 61 & 8 & 59 \\
\hline One-third & 148.8 & 19.3 & 256.3 & 87.1 & 9.4 & 187.6 & 68 & 9 & 69 \\
\hline One-fourth & 124.6 & 19.5 & 196.6 & 67.9 & 10.2 & 134.2 & 79 & 11 & 75 \\
\hline One-fifth & 105.7 & 14.9 & 171.4 & 58.4 & 7.0 & 119.8 & 135 & 21 & 133 \\
\hline Control & 104.5 & 14.5 & 155.4 & 56.4 & 6.7 & 108.1 & - & - & - \\
\hline
\end{tabular}


some of the components of biomass are of economic importance. However, the biomass, which could be recycled, is also in the same order of export as that in the biomass as far as treatments is concerned. It is interesting to note that the recyclable biomass obtained from two third level of fertilizer application was slightly more than full dose. The results are clearly indicated that if the recyclable biomass is composted properly and ploughed backed in to the system, there is further possibility of scaling down the dependence on chemical fertilizer and sustain the system.

From the above discussion, it may be concluded that in coconut and clove the yield and dry matter production was reduced considerably when the fertilizer dose was reduced below twothird level of recommended dose. In case of banana and pineapple, higher dry matter

production and economic yield is reported under full dose of recommended level and thereafter it was reduced gradually. It indicates that in order to realize their full potential banana and pineapple, should be fertilized with full dose of fertilizer and two-third level for coconut and clove is adequate under present situations.

\section{References}

Anonymous, 1995. Annual Report 1994-95. Central Plantation Crops Research Institute, Kasaragod, India, pp. 42-43.

Khanan, P.K. and Nair, P.K.R, 1977. Evaluation of fertilizer practices for coconuts under pure and mixed cropping systems in the west coast of India. Conf. on Classification and Management of Tropical Soils. Malaysian Soc. Soil Sci., Kuala Lumpur.

Manciot, R., Ollagnier, M. and Ochs, R. 1979. Nutrition minerale et fertilisation $\mathrm{du}$ cocotier dans le monde. Oleagineux 34: 499-510.

Nazeem, P.A, Wahid P.A and P.C. Sivaraman Nair, 1996. Nutrient status and annual nutrient removal of clove (Syzyctium aromaticum L. Merr. \& perror) J. Plant. Crops 24 (supplement): 110-115.

Ochs, R. and Ollaagnier, M. 1977. Effects of fertilizers on the composition of the lipids produced by perennial tropical oil plants and on their yield. Oleagineux 32(10): 409426.

Ouvrier, M.S. and Ochs, R. 1980. Nutrient removal by the hybrid coconut Port-Bouet 121 (MAWA). In Proceeding of International Conference on Cocoa and Coconuts. Incorporated Society of Planters. Kuala Lumpur-595-605, Malaysia.

Ouvrier. M and de Taffin, G. 1985. Evolution of mineral elements of coconut husks left in the field. Oleagineux 40(8 \& 9): 423430 .

Peng-Fang Ren, Huang-Bao Long, Tay-Ju Hana, Lim-Nam, Peng-F R, Huang-B L, Tay-J H, Lim-N. 1996. The structural characteristics and biomass productivity of coconutpineapple interplantation. J. Nanjing Fores. Univ. 20(1): 68-72.

Salam, M. A., Sreekumar, D. Mohanakumaran, N. and Babu, K.S. 1991. Coconut based homstead farming: a model. Indian Cocon. J. 22(4): 4-12.

Varghese, P.T., Nelliat, E.V. and Balakrishnan, T.K. 1978. Beneficial interactions of coconut-cocoa, crop combination. In Proc. PLACROSYM I, Nelliat, E.V., Ranganathan, V., Vishveswara, S., Potti, S.N. and Zachariah, P.K. (Eds.) Kasaragod, India, pp. 383-392. 